\title{
IMPACT OF COVID-19 PANDEMIC ON AIR QUALITY IN A TOURISTIC REGION
}

\author{
ANA CATARINA T. SILVA, PEDRO T. B. S. BRANCO \& SOFIA I. V. SOUSA \\ LEPABE - Laboratory for Process Engineering, Environment, Biotechnology and Energy, \\ Faculty of Engineering, University of Porto, Portugal
}

\begin{abstract}
The rise of the COVID-19 pandemic led governments to impose mobility restrictions to their citizens and companies, having a greater impact on tourism. This can be used as a global-scale opportunity to study the impact of those restrictions on air quality, particularly in tourist sites. Hence, the aim of this work was to evaluate the impact of the COVID-19 pandemic on air quality in a touristic region. Air pollution was evaluated in a prominent touristic region in southern Europe (Algarve, Portugal). The concentrations of $\mathrm{PM}_{10}, \mathrm{NO}_{2}, \mathrm{O}_{3}$ and $\mathrm{CO}$ were obtained from four air quality monitoring stations (traffic and background) in two lockdown and two lifting periods. The data collected was compared with historical data (2015-2019) and with reference limit values in the Portuguese legislation and the World Health Organization (WHO) guidelines. Overall, $\mathrm{PM}_{10}$ reduced in all studied periods and stations, with a higher decrease during the 1 st lockdown and lifting $(5.30 \%-73.6 \%)$ compared to the 2 nd periods in the urban traffic and background stations, as well as $\mathrm{NO}_{2}(35.8 \%-56.5 \%)$, in the urban background station evaluated. $\mathrm{O}_{3}$ diminished in general (until 29.1\%), while $\mathrm{CO}$ decreased during the 1 st lockdown and lifting periods $(64.5 \%-80.7 \%)$ and increased in the subsequent periods $(9.66 \%-65.1 \%)$ in the urban traffic station. The percentage of exceedances to the reference limit values both in the legislation and in WHO guidelines mainly decreased or remained equal in all the studied periods when compared with the previous years. Thus, it was concluded that the mobility restrictions imposed during the COVID-19 pandemic contributed to a general reduction of air pollution in tourist sites. Since tourism is an important economic activity, some specific policies were proposed based on those restrictions, considering a sustainable equilibrium between the economy, the environment, and human health. Keywords: air quality, COVID-19, lockdown, lifting, tourism, air pollution, SARS-CoV-2.
\end{abstract}

\section{INTRODUCTION}

On 11 March 2020 the World Health Organization (WHO) declared COVID-19 a global pandemic caused by the transmission of the SARS-CoV-2 virus, which forced the governmental entities to impose mobility restrictions on citizens and companies all over the world to prevent the spread of the virus [1]. Hence, investigating the influence of these restrictions on air quality can be a global-scale opportunity to understand their effects.

Among those mobility restrictions, the lockdowns (total or partial) consisted in one of the most restrictive policies adopted, enabling the reduction of traffic and socioeconomic activities [2]. As a consequence, air quality was claimed to improve in several studies conducted during the lockdown [3], [4]. Yet, some studies demonstrated that as soon as the lifting measures were adopted, the pollutants' concentrations increased nearly to the usual levels [5]. Regarding the socioeconomic sector, the pandemic had caused severe damages to it [6]. Attending the different socioeconomic activities, tourism was one of the most affected by the COVID-19 pandemic, especially during the 1st lockdown in 2020 which was the most restrictive of all the imposed lockdowns [7]. Currently, the touristic activity contributes largely to a country's socioeconomic dynamic. In Portugal, it is in the Algarve region where tourism contributes more to the economy since this is a worldwide recognised beach destination. Thus, it is important to study the impact of the pandemic on air quality in Algarve region in order to understand the extent of the air quality improvement in a region 
predominantly touristic that was strongly affected by the pandemic, not only during the 1 st lockdown but also in other subsequent restrictive periods.

As far as the authors' knowledge goes, only one study was published about the impact of the COVID-19 on air quality in Portugal, but it did not analyse data at a regional level, and it was only focused on $\mathrm{PM}_{10}$ and $\mathrm{NO}_{2}$ during the 1st lockdown in 2020 [8]. Therefore, the present study aimed to: (i) evaluate the impact of the pandemic on air quality in the touristic region of Algarve (Portugal), specifically on the concentrations of suspended particles with an equivalent aerodynamic diameter smaller than $10 \mu \mathrm{m}\left(\mathrm{PM}_{10}\right)$, nitrogen dioxide $\left(\mathrm{NO}_{2}\right)$, tropospheric ozone $\left(\mathrm{O}_{3}\right)$ and carbon monoxide $(\mathrm{CO})$, during the two total lockdowns and subsequent liftings imposed in 2020 and 2021; (ii) assess the impact in different types of air quality monitoring stations located in different environments, namely urban traffic, background and rural background stations; (iii) compare the data with the historical concentrations (2015-2019) and with the reference limit values in both the Portuguese legislation and the WHO guidelines; and (iv) define new policies for air quality improvement, considering a sustainable balance between the economy, the environment and the human health.

\section{METHODOLOGY}

\subsection{Data collection and study periods}

Hourly concentrations of $\mathrm{PM}_{10}, \mathrm{NO}_{2}, \mathrm{O}_{3}$, and $\mathrm{CO}$ were obtained between 1 January 2020, and 4 April 2021, from the air quality monitoring network of the Algarve region (southern Portugal). That network is composed of four monitoring stations located at Portimão (David Neto, urban traffic), Albufeira (Malpique, urban background), Faro (Joaquim Magalhães, urban background), and Alcoutim (Cerro, rural background), as represented in Fig. 1 [9].

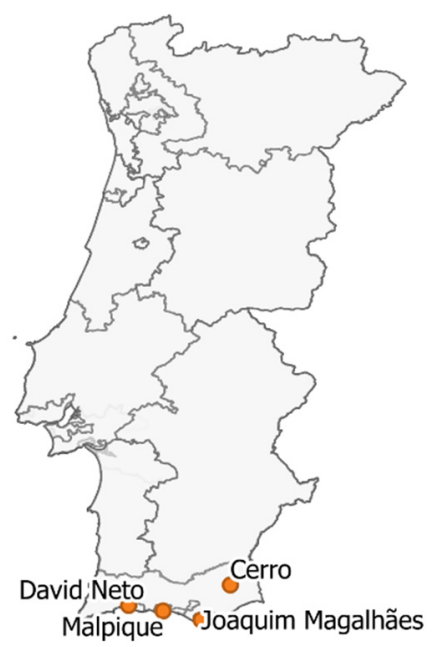

Figure 1: Location of the air quality monitoring stations from the Algarve region.

The hourly data from 1 January 2015 to 31 December 2019, were collected from the national database "QualAr" to be used as historical data for comparison with the 2020-2021 
data. The five previous years were considered to minimise the influence of the meteorological conditions on air pollutants' concentrations [8].

The study periods were defined according to the restrictive measures adopted in Portugal during the COVID-19 pandemic. On 16 March 2020 the first restrictive measures to prevent the spread of the virus were adopted, and a few days after, on 19 March 2020, the first state of emergency begun, which lasted until 4 May 2020 (the first day of the 1st lifting) [10][12]. During this period, major restrictions were imposed on citizens' mobility, leading to a widespread closure of services, mandatory curfew with exits only allowed for essential needs and work whenever remote work was not feasible [13]. After this period, 2020 and 2021 were marked by different lockdown and lifting periods, with the measures' restrictiveness varying according to the epidemiologic situation. Table 1 summarises the study periods defined, and the main restrictive measures applied in each defined period.

Table 1: Study periods defined based on the Portuguese national government's restrictive measures adopted in each period.

\begin{tabular}{|c|c|}
\hline Study period & Restrictive measures \\
\hline $\begin{array}{l}\text { I, 1st lockdown: } \\
16 \text { March-3 May } 2020 \\
{[13]}\end{array}$ & $\begin{array}{l}\text { Closure of all services that provide non-essential needs and } \\
\text { suspension of several activities, including schools and } \\
\text { religious events; } \\
\text { - All-day curfew for all citizens; exits allowed only for } \\
\text { essential needs; } \\
\text { - Circulation prohibited between municipalities (traffic } \\
\text { related); } \\
\text { - Suspension of flights and of the rail and fluvial means of } \\
\text { transportation (only allowed for essential goods transport); } \\
\text { - Mandatory remote work, whenever feasible. }\end{array}$ \\
\hline $\begin{array}{l}\text { II, 1st lifting: } \\
\text { 4 May-15 June } 2020 \\
{[12],[14]}\end{array}$ & $\begin{array}{l}\text { Permission for re-opening every type of commercial and } \\
\text { cultural places, like restaurants, coffee shops, museums, } \\
\text { etc.; } \\
\text { - Allowed events with } 20 \text { people or less; } \\
\text { - Re-opening schools for in person classes: nursery schools } \\
\text { and } 11 \text { th and } 12 \text { th grades, and schools for disabled people; } \\
\text { - Remote work still mandatory, but in-person work partially } \\
\text { allowed (reduced number of workers simultaneously). }\end{array}$ \\
\hline $\begin{array}{l}\text { III, 2nd lockdown: } \\
\text { 13 January-14 March } \\
2021[15],[16]\end{array}$ & $\begin{array}{l}\text { - Suspension of several activities and establishments that do } \\
\text { not provide essential needs; } \\
\text { - Circulation prohibited between municipalities (traffic } \\
\text { related); } \\
\text { - Only take-away regime or home delivery allowed for } \\
\text { restaurants and similar activities; } \\
\text { - Suspension of in-person educational activities, including } \\
\text { nurseries and schools, and other activities/ establishments of } \\
\text { social support. }\end{array}$ \\
\hline $\begin{array}{l}\text { IV, 2nd lifting: } \\
\text { 15 March-4 April } 2021 \\
{[17]}\end{array}$ & $\begin{array}{l}\text { - Re-opening of in-person classes in nurseries, pre- and } \\
\text { primary schools, and social support activities; } \\
\text { - Permission of travelling to other countries. }\end{array}$ \\
\hline
\end{tabular}




\subsection{Data analysis}

Daily mean concentrations of $\mathrm{PM}_{10}$ and $\mathrm{NO}_{2}$ were calculated based on a $50 \%$ data availability per day, while for $\mathrm{O}_{3}$ and $\mathrm{CO}$ the daily maximum of the 8 hours running mean was calculated based on a minimum of $75 \%$ of data per day as defined by the Portuguese legislation (Decreto-Lei no. 102/2010). The daily historical mean concentration was calculated using at least three of the five years considered ( $>50 \%)$.To be considered in the present study, a certain monitoring station was required to have at least $50 \%$ of the paired (historical 2020/2021) daily mean concentrations for each pollutant and period, and only the monitoring stations with data for the four periods for each pollutant were considered.

Descriptive statistics were used to express the concentrations of each pollutant in each monitoring station. Normality was assessed using the Shapiro-Wilk normality test. The parametric Student's $t$-test and the non-parametric Wilcoxon Rank-Sum test were conducted to test the significance of the differences between the study periods and historical pollutants' concentrations. The level of statistical significance was set at 0.05 . Furthermore, for each pollutant, the data was compared with the limit values defined in the Portuguese legislation (Decreto-Lei no. 102/2010) and in the WHO guidelines. Hence, $\mathrm{PM}_{10}$ concentrations were compared with the limit value/WHO guideline of $50 \mu \mathrm{g} / \mathrm{m}^{3}$, while $\mathrm{NO}_{2}$ were compared with the annual limit value/WHO guidelines of $40 \mu \mathrm{g} / \mathrm{m}^{3}$ that was used as daily limit. $\mathrm{O}_{3}$ was compared with the target value of $120 \mu \mathrm{g} / \mathrm{m}^{3}$ which is based on the daily maximum of the 8 hours running mean, and CO was compared with the limit value of $10 \mathrm{mg} / \mathrm{m}^{3}$.

Table 2 shows the identification code (ID), type, and the pollutants measured of each air quality monitoring station studied.

Table 2: Air quality monitoring stations evaluated from the Algarve region.

\begin{tabular}{|l|l|l|l|}
\hline Monitoring station & ID & Type & Pollutants studied \\
\hline Joaquim Magalhães & alg_01 & Urban background & $\mathrm{PM}_{10}, \mathrm{NO}_{2}, \mathrm{O}_{3}$ \\
\hline Malpique & alg_02 & Urban background & $\mathrm{PM}_{10}, \mathrm{O}_{3}$ \\
\hline David Neto & alg_03 & Urban traffic & $\mathrm{PM}_{10}, \mathrm{CO}$ \\
\hline Cerro & alg_04 & Rural background & $\mathrm{PM}_{10}, \mathrm{O}_{3}$ \\
\hline
\end{tabular}

\section{RESULTS AND DISCUSSION}

\subsection{Pollutants' behaviour}

The time-series plots of $\mathrm{PM}_{10}, \mathrm{NO}_{2}, \mathrm{O}_{3}$, and $\mathrm{CO}$ are represented in Figs 2-5, respectively, for each monitoring station and pollutant evaluated, for the 1st lockdown and lifting in 2020 (green) and 2nd lockdown and lifting in 2021 (red), and respective historical periods (blue).

Overall, the time-series pattern along the four periods was similar to the historical timeseries patterns for all the studied pollutants. Yet, some exceptions were denoted: (i) some peak concentrations of $\mathrm{PM}_{10}$ were observed during the I, II, III and IV periods, as a result of air mass intrusions from North Africa (Sahara and Sahel dust) that occurred on 19 March 2020, 29 May 2020, 15 February 2021, and 31 March to 4 April 2021, respectively [18][20]. Besides, at the beginning of January 2021 (winter season) an increase of $\mathrm{PM}_{10}$ levels occurred possibly due to the rise of residential wood combustion since this month was considered colder than usual over the last 4 years [21]; (ii) a relevant decrease of $\mathrm{O}_{3}$ concentration occurred between 1 and 15 April 2020, during the Period I, and in the second 

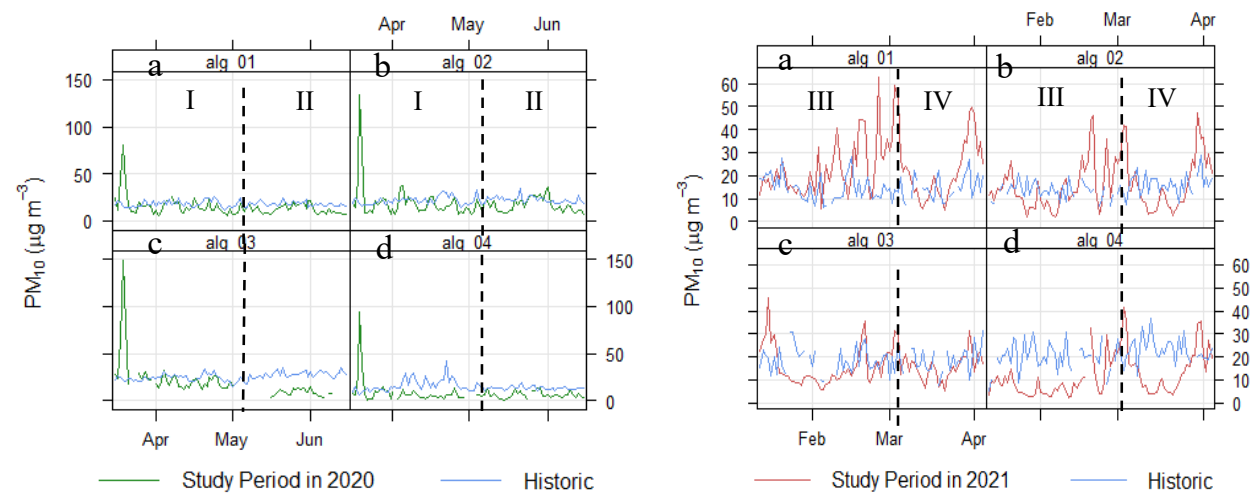

Figure 2: Time-series of $\mathrm{PM}_{10}$ for the historical and study periods in 2020 (1st lockdown - Period I, and 1st lifting - Period II) and 2021 (2nd lockdown - Period III, and 2nd lifting - Period IV) in the Algarve region air quality stations. (a) Joaquim Magalhães; (b) Malpique; (c) David Neto; and (d) Cerro.
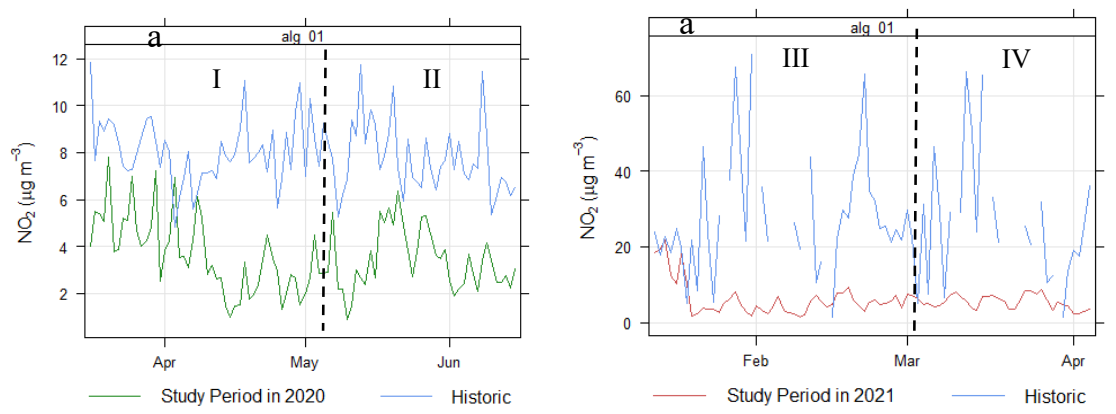

Figure 3: Time-series of $\mathrm{NO}_{2}$ for the historical and study periods in 2020 (1st lockdown Period I, and 1st lifting - Period II) and 2021 (2nd lockdown - Period III, and 2nd lifting - Period IV) in the Algarve region air quality stations. (a) Joaquim Magalhães.

half of January (Period III) due to anticyclones that occurred in Portugal with high levels of precipitation and low solar radiation, interfering with this pollutant formation [21], [22]. Besides, the reduction of $\mathrm{O}_{3}$ observed might be connected to the reduction of its precursors, namely $\mathrm{NO}_{2}$ at the urban background station (alg_01) studied for both.

\subsubsection{Period I: 1st lockdown}

During the 1st lockdown (Period I) the pollutants' concentrations generally reduced compared with the historical data. Hence, $\mathrm{PM}_{10}, \mathrm{NO}_{2}, \mathrm{O}_{3}$, and $\mathrm{CO}$ had statistically significant reductions (respectively, 5.30\%-46.3\%, 54.2\%, 0.75\%-16.48\%, and $80.7 \%, p$-value $<0.05$ ) 

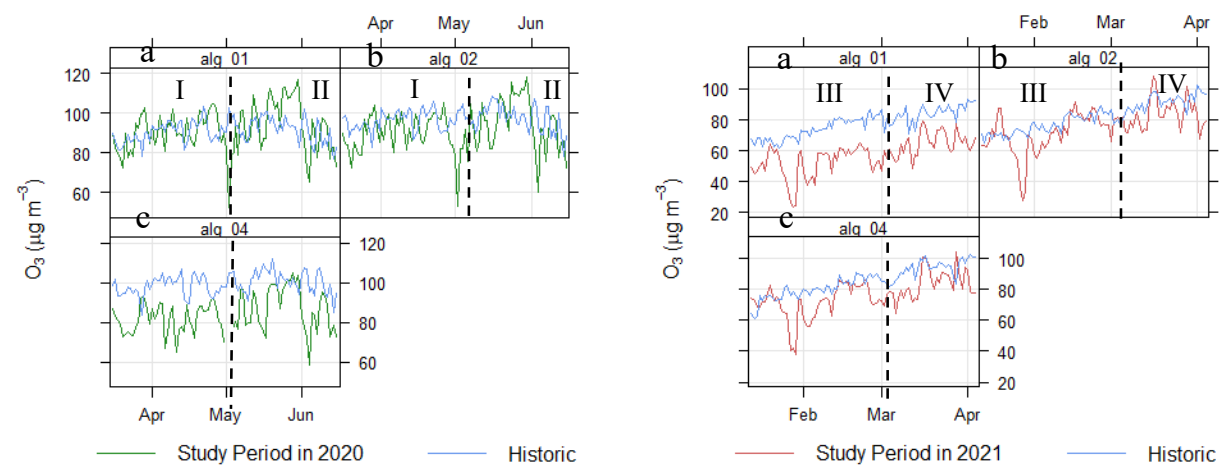

Figure 4: Time-series of $\mathrm{O}_{3}$ for the historical and study periods in 2020 (1st lockdown Period I, and 1st lifting - Period II) and 2021 (2nd lockdown - Period III, and 2nd lifting - Period IV) in the Algarve region air quality stations. (a) Joaquim Magalhães; (b) Malpique; and (c) Cerro.
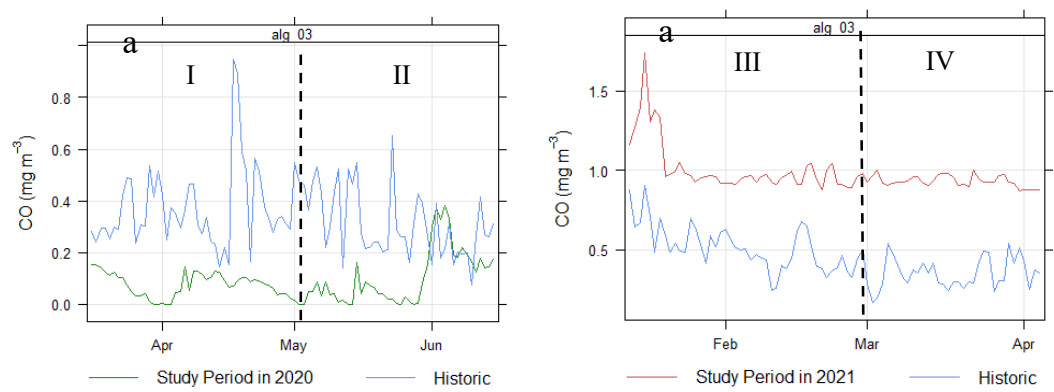

Figure 5: Time-series of CO for the historical and study periods in 2020 (1st lockdown Period I, and 1st lifting - Period II) and 2021 (2nd lockdown - Period III, and 2nd lifting - Period IV) in the Algarve region air quality stations. (a) David Neto.

in all stations, with the highest decrease observed at the urban traffic station for CO. Although the touristic activity in Algarve region is usually higher during the spring/summer months, these reductions were expected especially at the urban traffic stations given the restrictive measures imposed during that period, specifically the mobility restrictions and all-day curfew. Other studies also verified a general reduction of those pollutants' concentrations during the 1st lockdown, namely Broomandi et al. [23] in Iran (compared with 2019 data) and Dantas et al. [24] in Brazil (compared with pre-lockdown and 2019 data), except for $\mathrm{O}_{3}$ for which an increase was verified. However, Ordóñez et al. [25], who conducted a study in Europe, reported a decrease of $\mathrm{O}_{3}$ only in the Iberian Peninsula due to the low solar radiation during this period (compared with 2015-2019 data). The exceedances to the reference limit values were generally reduced to zero or remained equal to the verified in the historical period, except in the case of $\mathrm{PM}_{10}$ in the 1st lockdown when exceedances almost doubled those in the historical period, yet it should be noted the air mass intrusion that occurred during 
this period, as previously stated. Table 3 shows the differences (\%) between the concentrations in the study period and in the historical period and the percentage of exceedances in each monitoring station and pollutant.

Table 3: Differences (\%) between concentrations in the study period and in the historical data, and percentage of exceedances for $\mathrm{PM}_{10}, \mathrm{NO}_{2}, \mathrm{O}_{3}$, and $\mathrm{CO}$ for each monitoring station during the 1 st lockdown (Period I).

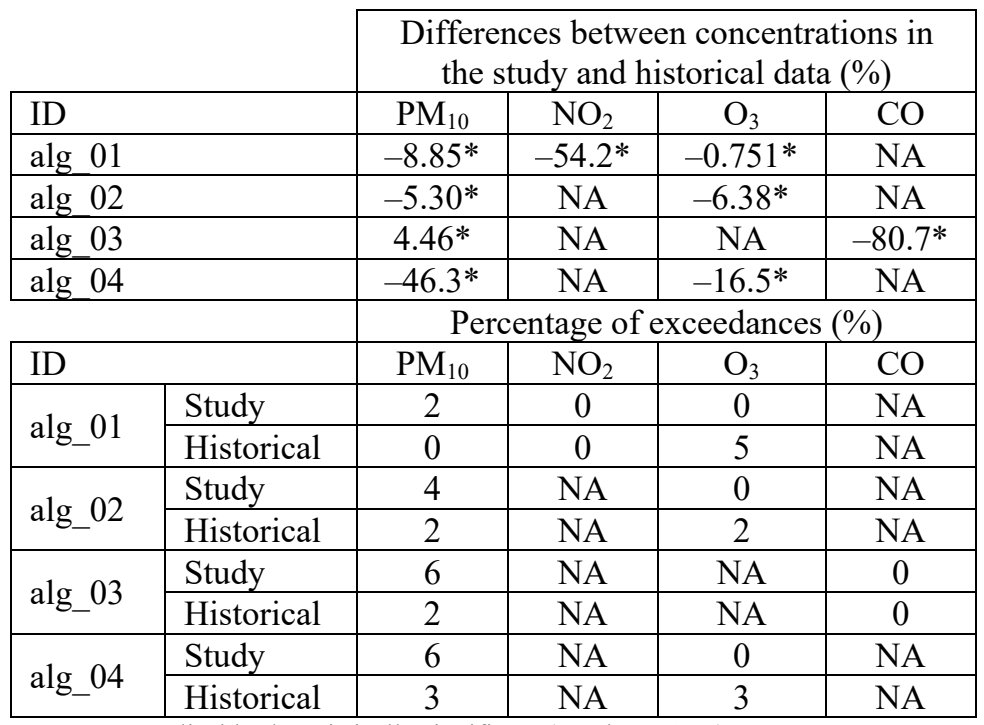

$\mathrm{NA}=$ not applicable; $*$ statistically significant $(p$-value $<0.05)$.

\subsubsection{Period II: 1 st lifting}

In the 1st lifting (Period II) the reductions of the studied pollutants' concentrations were in general higher than in the Period I, with statistically significant reductions ( $p$-value $<0.05$ ) of $25.5 \%-73.6 \%\left(\mathrm{PM}_{10}\right), 56.5 \%\left(\mathrm{NO}_{2}\right)$, and $64.5 \%(\mathrm{CO})$. In this period, $\mathrm{O}_{3}$ only evidenced a statistically significant reduction $(13.5 \%, p$-value $<0.05)$ at the rural background (alg_04, Cerro) station. The registered higher reductions in this period in comparison with Period I (the 1st lockdown) were expected. Although the restrictions regarding traffic mobility were lifted, the touristic activity usually increases largely during the spring/summer in the studied region. Thus, even though the 1 st lifting had less restrictive measures than the 1st lockdown, the usual touristic activity (pre-pandemic situation) was not re-established as the flights were still suspended, therefore lowering the number of tourists. In some cases, it was observed a reduction of the exceedances to the reference limit values from the historical period to zero exceedances in this study period, and in other cases they remained zero. Table 4 represents the differences $(\%)$ between the concentrations in the study period and in the historical period and the percentage of exceedances in each monitoring station and pollutant.

\subsubsection{Period III: 2nd lockdown}

During the 2nd lockdown (Period III) the concentrations of the studied pollutants reduced less in general than in the 1st lockdown (Period I). Hence, $\mathrm{PM}_{10}, \mathrm{NO}_{2}$, and $\mathrm{O}_{3}$ concentrations reduced by $5.1 \%-46.8 \%, 43.4 \%$, and $8.54 \%-29.1 \%$, respectively, statistically significant for all stations and pollutants $(p$-value $<0.05)$, with exception of two air quality monitoring 
Table 4: Differences (\%) between concentrations in the study period and in the historical data, and percentage of exceedances for $\mathrm{PM}_{10}, \mathrm{NO}_{2}, \mathrm{O}_{3}$, and $\mathrm{CO}$ for each monitoring station during the 1 st lifting (Period II).

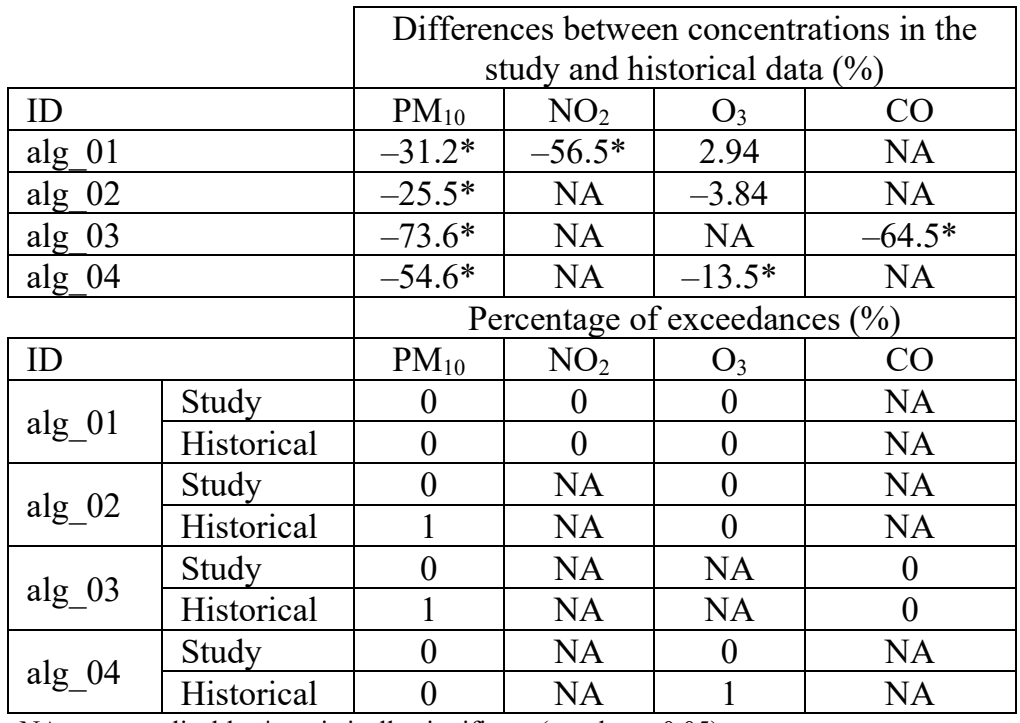

$\mathrm{NA}=$ not applicable; * statistically significant $(p$-value $<0.05)$.

stations for $\mathrm{PM}_{10}$, while $\mathrm{CO}$ concentrations significantly increased at the urban traffic station $(9.66 \%, p$-value $<0.05)$. Similarly to what happened in the 1 st lockdown, it was expected a decrease of the pollutants' concentrations comparatively to the historical data, because the mobility of the citizens was restricted. Yet, when comparing the results between the two lockdowns, in the 1st lockdown the reductions were all statistically significant, while in the 2nd lockdown not all were significant. This may be globally explained by the more restrictive measures of the 1st lockdown in comparison with the 2nd. Moreover, in the 2nd lockdown (Period III), it was possible to travel between councils during the weekdays, which was forbidden in Period I. Hence, this may also explain the slight increase in CO concentrations observed. In most of the stations and pollutants the percentage of exceedances to the reference limit values reduced to zero in the study period. Table 5 represents the differences (\%) between the concentrations in the study period and in the historical period and the percentage of exceedances in each monitoring station and pollutant.

\subsubsection{Period IV: 2nd lifting}

In the 2nd lifting (Period IV), the reduction of pollutants concentrations was lower than in the 1 st. $\mathrm{PM}_{10}, \mathrm{NO}_{2}$, and $\mathrm{O}_{3}$ reduced respectively by $14.9 \%-27.8 \%, 35.8 \%$, and $7.89 \%-21.6 \%$, whilst CO increased by $65.1 \%$. Besides, the number of statistically significant (p-value $<$ 0.05 ) reductions was lower in this period than in Period II (1st lifting). This was the period with the less restrictive measures considered in this study, with some restrictions being lifted like the allowance to fly and/or to travel between countries, which may have influenced the observed results, namely the increase of the $\mathrm{CO}$ concentrations at the urban traffic station. There were not found any exceedances to the reference limit values in this period, neither in the corresponding historical data. Table 6 represents the differences (\%) between the 
Table 5: Differences (\%) between concentrations in the study period and in the historical data, and percentage of exceedances for $\mathrm{PM}_{10}, \mathrm{NO}_{2}, \mathrm{O}_{3}$, and $\mathrm{CO}$ for each monitoring station during the 2 nd lockdown (Period III).

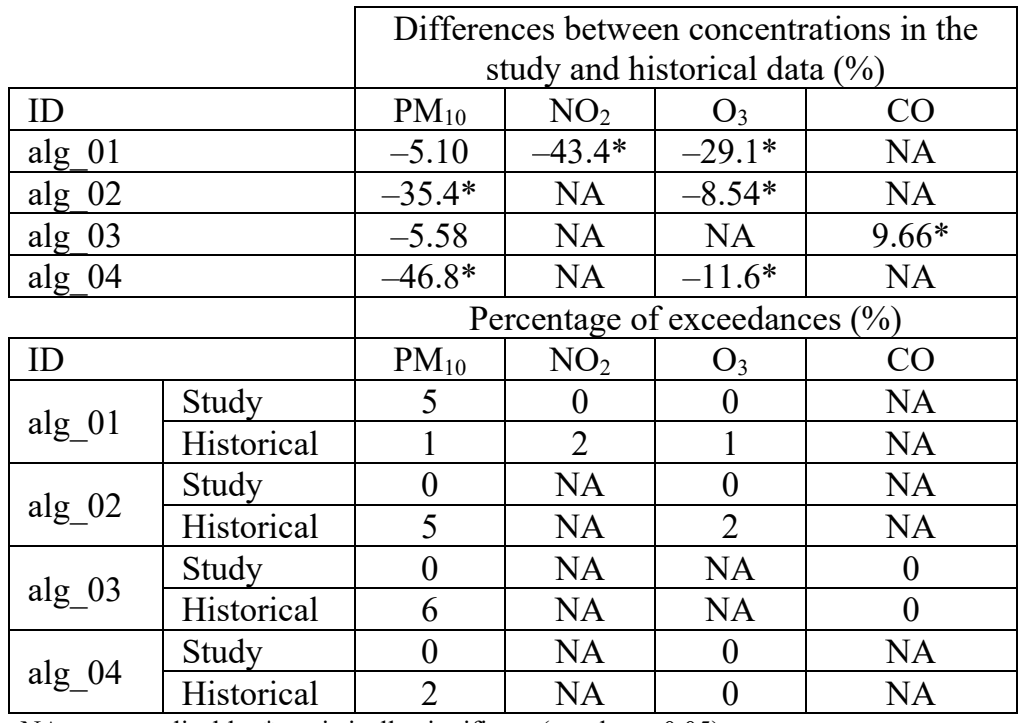

$\mathrm{NA}=$ not applicable; ${ }^{*}$ statistically significant $(p$-value $<0.05)$.

Table 6: Differences (\%) between concentrations in the study period and in the historical data, and percentage of exceedances for $\mathrm{PM}_{10}, \mathrm{NO}_{2}, \mathrm{O}_{3}$, and $\mathrm{CO}$ for each monitoring station during the 2 nd lifting (Period IV).

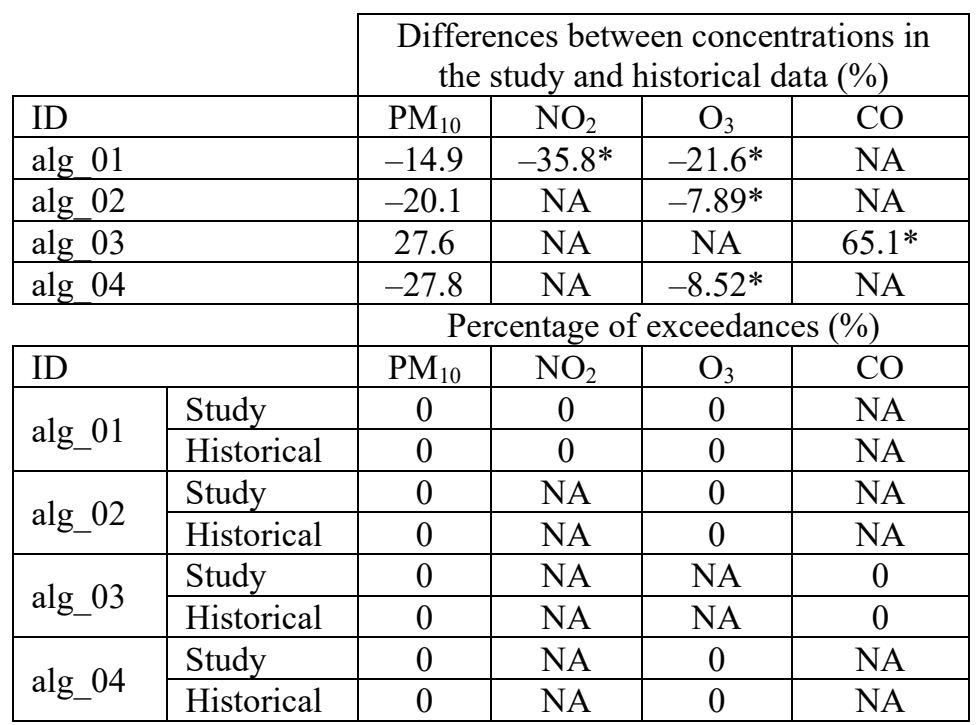

$\mathrm{NA}=$ not applicable; ${ }^{*}$ statistically significant $(p$-value $<0.05)$. 
concentrations in the study period and in the historical period and the percentage of exceedances in each monitoring station and pollutant.

\subsection{Proposed measures}

With the rise of the COVID-19 cases, several restrictions were imposed to prevent the spread of the infections by the SARS-CoV-2 virus, that led to a general reduction of the air pollutants' concentrations as evidenced in Section 3.1. Hence, some measures based on these results can be proposed to define new possible policies to improve air quality in the touristic region of Algarve. From all the restrictions stated in Section 2.1, the ones that mainly contributed to the pollutants' concentration reduction corresponded to the flights' suspension, all-day curfew, and the mobility restrictions, essentially adopted during the 1st lockdown and 1 st lifting. Nevertheless, these restrictions also had a severe impact on the touristic activity and consequently on the economy of this region. Therefore, any proposed measures for improving air quality should consider a sustainable equilibrium between the environment, the economy, and human health. During the 2nd lockdown and 2nd lifting, the restrictions imposed were less restrictive, and even though the reduction of the pollutants' concentration was not so high, air pollution still decreased overall. Thus, the restrictions imposed during these periods can be adopted to reduce air pollution with lower constraints on the touristic activities. As a short-term measure, the application of mobility restrictions between municipalities (like in the Period III, 2nd lockdown) when a high air pollution event is predicted would highly contribute to the decrease of pollutants levels, vis. by reducing emissions from transports (cars, taxis, etc). Aside this, soft means of transportation should be favoured as a more long-term measure. Given the good weather conditions of this seasonal touristic site (tourism mostly occurs in warm months), places like this should encourage tourists to walk/cycle. Additionally, more bike lanes and bike-rentals should be created. These measures will have a positive direct impact not only on the environment, but also on human health and the economy, as tourists could still travel to and within the region but using more sustainable means. This measure was also proposed by Piccoli et al. [26], aside from the urban planning re-design, which is highly recommended, especially for safe cycling and walking. Another related measure that should be established as soon as possible is the transition from fossil fuels to renewable energies in aircraft engines. Some studies have been developed in this matter, and the use of hydrogen as fuel (that is under development) seems promising since its electrolysis only produces water and heat [27]. Hence, since Algarve is predominantly a touristic region with tourists arriving mainly by plane, the local air quality would benefit from cleaner technologies in the aviation sector. Although the flights' suspension is a measure that clearly benefits the environment, it causes a relevant negative socioeconomic impact in the region, drastically reducing the touristic activity, then other measures with lower socioeconomic impact should be favoured.

\section{CONCLUSION}

The present work assessed the impact of the COVID-19 pandemic on air quality in the touristic region of Algarve, Portugal, considering the two lockdowns and respective liftings imposed in 2020 and 2021. Overall, the air quality improved during the four periods in all air quality monitoring stations relative to the historical data (2015-2019). Thus, it was possible to conclude that the restrictions imposed, even the less restrictive ones, positively impacted the air quality. $\mathrm{PM}_{10}, \mathrm{NO}_{2}$, and $\mathrm{O}_{3}$ concentrations consistently reduced in all the studied periods, while $\mathrm{CO}$ decreased in the 1st lockdown and lifting and increased in the 2nd lockdown and lifting. The reductions in the air pollutants' concentrations were higher in the 
1st lockdown than in the $2 \mathrm{nd}$ and in the 1 st lifting than in the $2 \mathrm{nd}$, especially of $\mathrm{CO}$ at the urban traffic station, since the mobility was more restricted than in the other periods. The percentage of exceedances to the reference limit values also reduced in all study periods in comparison with the historical periods, mostly to zero exceedances. Based on the results, and considering a sustainable equilibrium between the environment, the economy and the human health, some measures were proposed to define new possible policies to improve air quality in a beach touristic area like Algarve. Restricting citizens' travelling to and from the region and between municipalities was proposed as a short-term measure to be applied when a high air pollution event is predicted while encouraging tourists to use soft means of transportation (walking, cycling, etc.) was suggested as a long-term measure. Instead of banning flights, providing the transition from fossil fuels to more sustainable energy sources would benefit the air quality without wrecking the economy.

\section{ACKNOWLEDGEMENTS}

This work was financially supported by: Base Funding - UID/EQU/00511/2020 of the Laboratory for Process Engineering, Environment, Biotechnology and Energy - LEPABE funded by national funds through FCT/MCTES (PIDDAC). Sofia I.V. Sousa thanks the Portuguese Foundation for Science and Technology (FCT) for the financial support of her work contract through the Scientific Employment Stimulus - Individual Call CEECIND/02477/2017.

\section{REFERENCES}

[1] Cucinotta, D. \& Vanelli, M., WHO declares COVID-19 a pandemic. Acta. Biomed., 91(1), pp. 157-160, 2020. DOI: 10.23750/abm.v91i1.9397.

[2] Liu, F., Wang, M. \& Zheng, M., Effects of COVID-19 lockdown on global air quality and health. Sci. Total Environ., 755(Pt 1), 142533, 2021.

DOI: $10.1016 /$ j.scitotenv.2020.142533.

[3] Filonchyk, M., Hurynovich, V. \& Yan, H., Impact of COVID-19 lockdown on air quality in the Poland, Eastern Europe. Environmental Research, 198, 110454, 2021. DOI: 10.1016/j.envres.2020.110454.

[4] Ganguly, R. A.-O., Sharma, D. \& Kumar, P., Short-term impacts of air pollutants in three megacities of India during COVID-19 lockdown. 2021.

DOI: $10.1007 / \mathrm{s} 10668-021-01434-9$.

[5] Kumari, P. \& Toshniwal, D., Impact of lockdown on air quality over major cities across the globe during COVID-19 pandemic. Urban Climate, 34, 100719, 2020.

DOI: 10.1016/j.uclim.2020.100719.

[6] Kar, S. et al., Impact of coronavirus (COVID-19) outbreak on society, air quality, and economy in India: A study of three "p"s of sustainability in India. Sustainability (Switzerland), 13(5), pp. 1-27, 2021. DOI: 10.3390/su13052873.

[7] Porto Business School, O impacto da COVID-19 no setor do turismo. 2020.

[8] Gama, C., Relvas, H., Lopes, M. \& Monteiro, A., The impact of COVID-19 on air quality levels in Portugal: A way to assess traffic contribution. Environmental Research, 193, 110515, 2021. DOI: 10.1016/j.envres.2020.110515.

[9] Comissão de Coordenação e Desenvolvimento Regional do Algarve (CCDR Algarve), Qualidade do Ar na Região do Algarve - Relatório $2^{\circ}$ Trimestre de 2015, 2015.

[10] Presidência da República, Decreto do Presidente da República no. 14-A/2020. Diário da República 1. ${ }^{\mathrm{a}}$ série, 55(March), pp. 13-(2)a-(4), 2020. 
[11] República Portuguesa, Comunicado do Conselho de Ministros de 19 de março de 2020, 2020. https://www.portugal.gov.pt/pt/gc22/governo/comunicado-de-conselho-deministros?i=334. Accessed on: 22 Mar. 2021.

[12] República Portuguesa, Comunicado do Conselho de Ministros de 30 de abril de 2020, 2020. https://www.portugal.gov.pt/pt/gc22/governo/comunicado-de-conselho-deministros?i=344. Accessed on: 21 Mar. 2021.

[13] República Portuguesa, Comunicado do Conselho de Ministros eletrónico de 16 de março de 2020, 2020. https://www.portugal.gov.pt/pt/gc22/governo/comunicado-deconselho-de-ministros?i=332. Accessed on: 22 Mar. 2021.

[14] República Portuguesa, Comunicado do Conselho de Ministros de 9 de junho de 2020, 2020.

[15] República Portuguesa, Comunicado do Conselho de Ministros de 13 de janeiro de 2021, 2021. https://www.portugal.gov.pt/pt/gc22/governo/comunicado-de-conselhode-ministros? $\mathrm{i}=394$. Accessed on: 4 Apr. 2021.

[16] República Portuguesa, Comunicado do Conselho de Ministros de 21 de janeiro de 2021, 2021. https://www.portugal.gov.pt/pt/gc22/governo/comunicado-de-conselhode-ministros? $\mathrm{i}=397$. Accessed on: 4 Apr. 2021.

[17] República Portuguesa, Comunicado do Conselho de Ministros de 11 de março de 2021, 2021. https://www.portugal.gov.pt/pt/gc22/governo/comunicado-de-conselho-deministros?i=407. Accessed on: 4 Apr. 2021.

[18] Macedo, C., APA alerta para ocorrência de fraca qualidade até esta sexta-feira. Ambiente Magazine, 19 Mar., 2020.

[19] Agência Portuguesa do Ambiente (APA), Previsão de transporte de partículas naturais com origem em regiões áridas, 2020.

[20] Agência Portuguesa do Ambiente (APA), Previsão de transporte de partículas naturais com origem em regiões áridas, 2021.

[21] Instituto Português do Mar e da Atmosfera (IPMA), Boletim Climatológico Portugal Continental Janeiro 2021, 2021.

[22] Instituto Português do Mar e da Atmosfera (IPMA), Abril 2020 Portugal Continental, 2020.

[23] Broomandi, P., Karaca, F., Nikfal, A., Jahanbakhshi, A., Tamjidi, M. \& Kim, J.R., Impact of COVID-19 event on the air quality in Iran. Aerosol and Air Quality Research, 20(8), pp. 1793-1804, 2020. DOI: 10.4209/aaqr.2020.05.0205.

[24] Dantas, G., Siciliano, B., França, B.B., da Silva, C.M. \& Arbilla, G., The impact of COVID-19 partial lockdown on the air quality of the city of Rio de Janeiro, Brazil. Science of The Total Environment, 729, 139085, 2020.

DOI: 10.1016/j.scitotenv.2020.139085.

[25] Ordóñez, C., Garrido-Perez, J.M. \& García-Herrera, R., Early spring near-surface ozone in Europe during the COVID-19 shutdown: Meteorological effects outweigh emission changes. Science of The Total Environment, 747, 141322, 2020.

DOI: 10.1016/j.scitotenv.2020.141322.

[26] Piccoli, A. et al., Modeling the effect of COVID-19 lockdown on mobility and $\mathrm{NO}_{2}$ concentration in the Lombardy region. Atmosphere, 11(12), pp. 1-18, 2020. DOI: $10.3390 /$ atmos11121319.

[27] Airbus, Is this the next "clean" energy to power aviation? 2020. https://www.airbus.com/newsroom/stories/Is-this-the-next-clean-energy-to-poweraviation.html. Accessed on: 24 Aug. 2021. 